\title{
A 'THICK DESCRIPTION' OF TWO BIBLE STUDIES BY THE BELHAR LIGHTHOUSE GROUP
}

\author{
Douglas G Lawrie \\ Department of Religion and Theology \\ University of the Western Cape
}

\section{Profile of the group}

This group functions as a "cell" of the Lighthouse, a relatively new Pentecostal church in the Cape Peninsula. The members of the group are virtually all people who belonged to other churches before they joined the Lighthouse. Beneath the surface of "Lighthouse theology", which is charismatic and conservatively evangelical (with a strong emphasis on personal conversion), one thus finds traces of many different ecclesiastical traditions.

The members of this particular group come from Belhar, a predominantly Coloured community. ${ }^{1}$ According to my information, ${ }^{2}$ the members of the group are mainly artisans, factory workers, municipal workers and others with a relatively small but steady income. They are, in other words, not desperately poor, but also far from wealthy. One could place them at the lowest end of the middle class or in the upper bracket of the working class. There are actually two groups, a youth group and an adult group. For the first of the two recorded sessions, the two groups met together, but members of the youth group did not contribute very much to the discussion. In my description I shall concentrate on the adult group. Both groups are mixed with regard to gender and in the adult group there is a considerable mix of age groups. It was interesting to see that working men of between 25 and 45 made up a fair proportion of the adult group.

The group has been functioning as a Bible study, prayer and support group for some two years. It meets regularly on Wednesday evenings in the houses of members. Though there is a core membership, the meetings are not attended by the same people each week and attendance varies from around 12 to around 20. Members are encouraged to bring visitors, thus the meetings also have a "missionary" aspect. One can hardly get to grips with the mode of interpretation in this group without considering the dynamics within the group. This is not a Bible study group in the ordinary sense. Only the group leader, brother Bernard, comes to the meetings prepared. He frequently reads from notes, apparently taken from various sources. His leadership seems to be very important to him: he tries to have both the first word and the last word and a good many in between. He also tends to provide "authoritative" comment on whatever anyone else says. His preparation, which includes references to Greek words, becomes an instrument to confirm his leadership. He is the one who knows and therefore has the right to exercise leadership.

Since brother Bernard does most of the talking, the observer from outside the group finds it hard to get a clear picture of the interpretative dynamics of the group. Brother Bernard comes across as domineering (his physical appearance and body language adds to this impression) and excessively concerned with his own knowledge and importance. In spite of his preparation, he is not a coherent speaker: he meanders, repeats himself

1. During the Apartheid era, Belhar was established as a Coloured township. As far as I could make out (and taking into consideration the inherent instability of such classifications), all the members of this group are "Coloureds".

2. For my information on the group, I depend on Ms Lutasha Abrahams, a student who lives in Belhar and has attended meetings of the group. 
endlessly and has the irritating habit of using the word "eintlik" (actually) at least once in almost every sentence. It is easy to dismiss him as a typical lower middle class male with something of an inferiority complex, who uses his position in the church to bolster his ego. Once he mentioned that God can work with anything: God does not require degrees or property. This may be a reflection on his own position. At the same time, the members of the group seem to react in a far too submissive manner. Although they apparently do not always agree with him, they never challenge his authority.

Although this is no doubt partly true, it does not seem to me to be the whole story. Certainly, there is something of the desperate struggle to be respectable that often marks the bottom end of the middle class, the class without a realistic hope of attaining a higher social status and always in peril of slipping down one step further. Perhaps it is not surprising or reprehensible that a church group should function as a bastion in this struggle and a source of strength for the members. But there is more to it than that. Brother Bernard expresses himself badly, yet he is not stupid. He rules the roost and is eager to show off his preparation, but in his way he tries to stimulate discussion. He lacks training for his role, yet he might not be unwilling to learn. As for the members of the group, a second viewing convinced me that they did not treat brother Bernard with undue awe. Instead, many of them seem to accept him, ${ }^{3}$ possibly because they have an instinctive understanding of his position. This tolerance is also extended to other members of the group. There does not seem to be severe tension within the group. Nevertheless, the search for an adequate interpretation is not marked by as much co-operation as in the case of the Sokhanya group. Lastly, although the element of mutual support is prominent, there seems to be an honest eagerness to interpret and apply the Bible. There is some intellectual activity evident in the group.

\section{A brief description of the sessions}

\section{General:}

The long meetings (they may last for more than 90 minutes) usually start with the singing of choruses and songs of praise. This part of the meeting is quite charismatic and includes clapping of hands and swaying. The middle session is devoted to something between a sermon and a Bible study. The members do not (normally) know beforehand what passage from the Bible will be discussed, therefore the leader, brother Bernard, does a lot of the talking. He does, however, invite responses from the members of the group. Towards the end, the discussion usually becomes more general, as the members cite favourite verses from the Bible, give testimonies and tell of their problems. At this stage the group clearly functions as a support system. The meetings close with prayers. Both the recorded sessions followed roughly this pattern, although in this case the members did know what passages were to be discussed.

\section{Session 1: Matthew 13: 53-58:}

According to the normal pattern, brother Bernard introduced the passage after it had been read aloud (by members of the group) from different translations. He pointed out that the audience asked five questions about Jesus (cf verses 54-56) and concluded that the passage stresses these questions. He then asked the group why Jesus' audience took offence.

3. Ms Abrahams has confirmed to me that brother Bernard is well liked, both in the community and in his church. He is apparently known for his jokes. 
The first response was that Jesus was scorned because he was the son of a carpenter, a member of the middle class and not the upper class. Another one added that he was too "common" for them and that they may have been jealous of his wisdom. Some variations on this theme were then explored. One member compared the passage to John 1:11. Jesus' own people, the Jews, rejected him, but then those who do the will of God are the true family of Jesus (cf Mark 331-35 and parallel passages). The same person suggested that they could not believe that this ordinary man could be the Son of God, referring to verse 58, where lack of faith I mentioned.

The response to this last point was interesting. Brother Bernard intervened (after another question about Jesus as God) and tried to explain (not very coherently) that Jesus had to be fully human and to experience what all human beings experience - otherwise He would have had "no legal right on earth". He returned to this point a little later and stressed that the people of Nazareth rejected Jesus as prophet. One may regard this as an attempt to dismiss the offered interpretation tactfully by saying that the audience was not supposed to recognise Jesus as God. Lack of faith in Jesus as Son of God could therefore not be the issue. Brother Bernard also used this opportunity to say that we are capable of all things in Jesus (cf Philippians 4:13). Apparently the kenosis of Jesus is here linked to the elevation of Christians.

When the group returned to the question as to why Jesus was rejected as prophet, one member suggested that his message was not acceptable to them because He saw through their hypocritical religion. At this stage they did not compare the passage to its parallel in Luke. They did not, for instance, consider the possibility that Jesus was rejected because he preached an unpopular message of liberation. Admittedly, even the Lukan text contains nothing to suggest that the liberation theme as such evoked the negative reaction from the audience. Brother Bernard pointed out that other prophets had also been rejected, but he did not pursue the point. Instead, the theme that Jesus' was simple too ordinary kept coming up: one member suggested that the more important people ("hogere mense") were the ones who rejected Jesus.

Brother Bernard then tried to summarise this line of thought while simultaneously applying it to his audience. Jesus was a man from the ghetto, because Nazareth was the equivalent of Crossroads. ${ }^{4}$ Nothing good was expected from Nazareth. For such a person to act as a prophet scandalised ${ }^{5}$ the people of Nazareth. They knew his background and family and could not see him as someone special. Much the same thing happens when a drunkard is converted: people ignore him or scorn him, because they know his background. They do not recognise that Jesus has the power to renew the lives of people, thus completely separating them from their past. But, brother Bernard warned, if we do not walk completely with Jesus, our backgrounds can indeed influence our lives negatively. The clear conceptual gap between the interpretation (Jesus' background as an ordinary person in Nazareth) and the application (our background as sinners before conversion) suggests that the theme of conversion and renewal of life is crucial to the group.

This application found favour with the group. Several pointed out that people may expect rejection and ridicule after their conversion and cited examples from their own experience. That Jesus was rejected as prophet gained new significance in this setting. As

4. Crossroads is a large squatter camp on the Cape Flats.

5. Brother Bernard played around with the verb skandalizein in verse 57 and got drawn into somewhat irrelevant comments about scandals, stumbling blocks and giving offence. For instance, he talked about the stumbling blocks Christians should expect to encounter and about the fact that the lives of believers will offend (be a stumbling block to) non-believers. 
the group pointed out, people met with rejection and ridicule especially when - after their conversion - they tried to preach to their families and former friends. At such times they were confronted with their "background".

Since this application so patently fitted in with the needs of the group, it is worth noting that two members of the group suggested alternative views at a late stage. The one who had introduced John 1:11 earlier returned to this theme. That Jesus' own people, the Jews, rejected Him was part of God's plan. This rejection opened the way for the gentiles (perhaps he had Romans 11 in mind), thereby paving the way to our salvation. Therefore the passage gives us reason to be thankful. Another member drew what she herself called a more practical conclusion. We should be more ready to recognise spiritual gifts in others, also in those who appear unlikely candidates.

In the conclusion, however, the other view prevailed. As brother Bernard put it, we have to expect rejection and ridicule -after all, this is what Jesus also experienced. Jesus went ahead of us and paved the way and we are expected to follow in his footsteps (the reference seems to be to the argument in Hebrews - taken out of context). Because God is faithful, we should not lose courage when we are rejected. The passage calls us to trust God and to persist. Towards the end, one speaker summarised this line of thought in its crudest form: rejection by unbelievers actually shows how close we are to God. Another said that the passage should make us feel good, even when we are rejected.

This session was not completely recorded, but it is probable that not much was lost. The last section of the tape shows that the group way already moving towards "sharing" and more general conversation.

\section{Session 2: Luke 4: 14-32:}

For this session the group had to respond to the following input from the research team that drew their attention to a particular interpretation of this passage in the tradition of liberation theology:

Luke 4:14-22 can be interpreted in very different ways. In liberation theology it is often regarded as a key text. After all, the quote from Isaiah emphasises that the gospel is preached to the poor. It promises freedom for (political?) prisoners, liberation for the oppressed and a year of grace (the Jubilee) for those who are indebted. In the gospel of Luke this is the first sermon that Jesus preached (and in his own town of Nazareth). This may therefore be understood to be the very heart of the message and ministry of Jesus: liberation for the poor and the oppressed.

What do you think? Do you agree with this emphasis in liberation theology? Why would the poor people of Nazareth be so angry about this message (verse 28-29)?

In this very long session the group did not discuss the passage as a whole, but focused on two questions: Is the interpretation of liberation theology acceptable? What is the significance of the Jubilee? During this session brother Bernard did not intervene quite as often and he actually made quite an effort to extract views from the members of the group.

After the customary readings of the passage and the reading of the input provided by the research group, brother Bernard gave a brief introduction, noting that the passage talks about the fulfilling of the prophecy in Isaiah 61. Then, with regard to the interpretation of liberation theology, he asked pertinently, "Can one take the Word of God in this way?" ("Kan jy die Woord van God so vat?"). The tone in which he asked the question showed clearly that he expected a negative answer. ${ }^{6}$ More concretely, does the passage specifically refer to political prisoners when it talks about the freeing of prisoners?

6. Later on he repeated this question several times, each time in the same tone. 
The first member to respond, Wayne (who was not present the previous time), felt that political prisoners were certainly included. But, he added, the reference must not be taken too narrowly. "Prisoners" are all those who are not saved, "all those out there" ("almal daarbuite"). The next speaker agreed entirely, saying that the passage does not refer only to those who are physically imprisoned. People can also be prisoners of their sins; for instance, many people are prisoners of alcohol or drugs. What is very interesting is that she felt that that context of the passage suggests that an overly literal reading is not appropriate. Although the political interpretation touches on one valid aspect, there is no good reason to focus on this aspect to the exclusion of others. Another member picked up on the point about the context later. She pointed out that it would be difficult to understand the reference to the blind in a purely physical sense, because there are still Christians who remain blind. For her it followed that both blindness and imprisonment have to be taken metaphorically.

Whereas the first two speakers did not exclude a political interpretation completely, others who took a similar stance showed a greater distrust of politics. Several members of the group felt strongly that religion and politics do not mix well ("Ek like nie die Woord met politiek nie"). They did not merely see the political interpretation as limited, but regarded it as dangerous. Brother Bernard later endorsed this view when he branded politics as "worldly and humanistic" ("wêrelds en humanisties"). Jesus, he said, is not really talking about politics - it is not a matter of politics "at all" ("geensins"; twice). When he kept pressing the question of the validity of the political reading after several members had responded, he seemed to be insisting on a total rejection of such readings.

The negative attitude to political interpretation of the Bible took different forms. One said succinctly, "We poor don't know about politics" ("Ons armes ken niks van politiek nie"). Another member, a youngish man who seems to be fairly educated, complained that in his previous church (during the Apartheid era) much of the preaching was simply political propaganda; it did not focus on Jesus on the cross. Therefore he remained blind to the purpose that there is in each of our lives. His objection seems to be that political preaching did not meet his need to find meaning in his life.

Not all the members rejected political action completely. One spoke of the struggle for justice and brother Bernard himself referred to the group's experience of oppression under Apartheid ${ }^{7}$. One member argued that politics should not be seen simply as a matter of political parties. She regarded as valid political engagement the struggle of the church to establish God's reign ("God se bestel"), by opposing, for instance, legalised abortion, prostitution and Cape Town as gay city! According to her, it is (now) a matter of contesting legislation, especially when those who support the legislation are prisoners of money. Brother Bernard also made a distinction between "worldly politics" and "church politics". Worldly politics, he said, stands condemned because everything can now be justified if it is done "for political reasons". In short, the sphere of politics is perceived as one of manipulation, deceit and narrow interests. Church politics differs from worldly politics in that it aims at the total renewal of everything (brother Bernard). In a telling remark, one member suggested (referring to Galatians) that the political sphere is "still under the law".

While these remarks on political interpretation were being made, others explored what they regarded as the correct interpretation of the words of Jesus. Wayne argued that, since Isaiah's prophecy was fulfilled in Jesus, the words now apply to us. We should visit those in prison and pray for the blind and the sick. In this way we would continue the work of Jesus. The majority expounded various ways in which people today - both believers and

7. One member introduced, neither subtly nor coherently, the case of Allan Boesak. Her point seems to be (but it remains unclear to me after three viewings) that Boesak's sentence may work out well for him and for the prisoners: he gets a fair opportunity ("regverdige kans") to use his talents in the service of the gospel. 
unbelievers - can be "blind" or "imprisoned". Many of us are still blind to some sins in our lives; we are not yet freed of some "hidden things". Moreover, we need to be freed from temptation. Brother Bernard said that it is worse to be a prisoner of yourself than to be behind bars. On the other hand, Paul, even when he was in jail, was a free man.

The majority thus preferred to focus on spiritual liberation, although some were prepared to include political aspects. Before we can change the world, we have to be changed ourselves. There were references to those caught in the enemy's claws ("in die kloue van die enemy") or in the devil's claws ("vasgevang in die duiwel se kloue"). God's grace towards the individual remained the centre of interest - the main point is God's grace in our lives (brother Bernard ${ }^{8}$ ).

The rest of the discussion concerned the meaning of the Jubilee. In this regard, the group showed considerable ability to generate questions and answers. Having established that the Jubilee concerned remission of debts and that it normally took place every 50 years in Israel, one member suggested that the reference in Isaiah 61 might be to the end of time, the eschatological feast. Another member then asked to what time Jesus was referring, raising, in effect, the problem of realised eschatology. From the text one group member concluded that the time of the Jubilee has to start with the very words of Jesus.

Those who took a strong line on realised eschatology (brother Bernard, for one) tended to spiritualise the Jubilee. It concerns remission of sin and a new beginning. "I experience Jubilee" in all aspects of my life, according to one group member. "Each day with God is a Jubilee", according to brother Bernard ("Elke dag met God is Jubilee"). Although some did say that the Jubilee involved prosperity in all its aspects, including the financial one, the main emphasis was on the renewal of the mind and the heart. Jubilee indeed signals a fresh start, but one in which we are free of the debt of sin.

The distinction between the two dispensations was also explored. It was pointed out that we no longer practise the Jubilee in the old way. We are no longer living in those times ("daai jare"), but our position is actually better. We do not have to wait for fifty years!

But clearly all is not good news in our actual lives. The group grappled with the fact that Christians still experience problems in their lives. Some suggested that it sometimes takes time for the reality of the Jubilee to work through to all aspects of life; others warned that we cannot take grace "for granted" and that the problems remind us of our responsibility. The most popular view was that God's grace has already been given, but that we have to claim it to make it a reality. In this regard human free will was mentioned - God can only help us if we allow it. It was also said that we should continue to "search the Scriptures" for daily liberation and renewal. The idea that we have to grasp the promise in faith seemed to be the main line of application.

\section{Response to the world behind the text}

As one may expect, there was not much understanding of the historical and cultural distance separating the biblical context from ours. This seems to be the result of ignorance and does not necessarily mean that the categories of history and culture play no role in their interpretation. Indeed, brother Bernard once mentioned "the cultural and historical

8. The point about grace is made in a somewhat puzzling monologue by brother Bernard. Apparently his argument runs as follows: Jesus' audience expected a political Messiah, one who would first destroy Israel's enemies. But when Jesus reads from Isaiah 61, He omits the reference to God's vengeance in Isaiah 6:2. Jesus' message is thus one of grace without punishment. Brother Bernard does not, however, make this point very clearly and one wonders whether this is because he expresses himself badly or because he is quoting from sources he did not fully understand. 
background." When they try to understand the passages by means of analogies ("carpenter" is "middle class, not upper class" and Nazareth "is like Crossroads" or a ghetto), it is clear that the group is both willing and able to use what knowledge they have or think they have. Brother Bernard's remarks on Greek words may be a response to a perceived need. The need for knowledge and even for theological training was mentioned more than once. It is significant that these remarks were not simply dismissed by referring to the superior spiritual wisdom of the faithful.

Lacking other resources, brother Bernard and others in the group depended on the knowledge they do have. They "compare Scripture with Scripture" (brother Bernard cited this principle explicitly). The outcomes are sometimes a bit wayward, but it is important to see that this is not necessarily the result of choosing an interpretative strategy, but rather the result of a lack of choice. In dealing with the Lukan passage, they drew on information that was given to them. Their discussion of the problem of the Jubilee indicates that they are able to integrate information into their sessions (see above). One member made good use of the difference between the two dispensations. Even the (old) Jubilee is "still under the law", therefore the new Jubilee is significantly different. This type of argument probably owes much to knowledge of Paul's strategies.

\section{Response to the world of the text}

With regard to genre and literary structure, the group was at sea. Again, one cannot conclude that there is a total lack of interest in this aspect. It is most unlikely that the popular sources brother Bernard used would have provided much guidance. Brother Bernard tried to make something of the structure by noting the prominence of five successive questions in Matthew 13:54-56. Having detected this "structure", however, he was at a loss as to what to do with it. It is clear that they all read both passages as unproblematic historical accounts. On the other hand, some members showed an awareness of the poetical genre of the Isaiah passage when they argued against a completely literal interpretation.

In the first session they focused entirely on the rejection of Jesus and the reasons for it, but this does seem to be the emphasis of the text. They do not make an effort to link the two passages, thereby relating the rejection of Jesus to his message of liberation. Nevertheless, brother Bernard was not necessarily wrong when he emphasised that Jesus was rejected as a prophet (not as an agitator). What Jesus says in Luke 4:21 is not grammatically linked to the acts of liberation as such but to the claim to be inspired by the Spirit to proclaim the message of liberation (Luke 4:18). Jesus claims to speak prophetically and is rejected as prophet (cf. Matthew 13:57).

In view of some of the group's elaborations on the theme of Jesus' rejection, one is tempted to call their approach midrashic. A careful second viewing showed something else. At the beginning of the first session, the group stuck to the question: Why was Jesus rejected? They came up with a number of possible answers. The very first answer and the one to which the group returned most often is that Jesus was simply too familiar. As the group noted, this fitted with the reference to the surprise at Jesus' wisdom.

When persistent questioning forces one to look beyond simple, plausible answers, one is likely to come up with elaborate, less plausible ones. The suggestion about jealousy ("nydigheid") is a case in point. In the type of community within which this group finds itself, those who rise above the rest in any way are frequently the targets of envious

9. The Afrikaans word refers to malicious actions arising from jealousy and not simply to the feeling of jealousy. 
deprecation. He passage itself does not, however, offer clear support for this interpretation. My conclusion is that the group started off sensibly enough, but drifted toward the fanciful once they failed to find more to say about the text. When pesher had nothing more to offer, they fell back on midrash. Perhaps they always do this; perhaps this first passage offered them too little (in view of their long sessions). It is certainly true that at the end of both sessions, the biblical text virtually disappeared, but, as I noted above, this is apparently the general pattern of these meetings: Bible study makes way for "sharing" and personal comment. It would perhaps be unfair to judge their mode of interpretation of the Bible on the basis of this.

\section{Response to church tradition}

The Lighthouse is Pentecostal in orientation, but the group is not by any means extreme in this regard. I counted two or three (restrained) interjections of "Praise the Lord" and "Hallelujah". The ruling theology is, instead, typically evangelical: quite conservative, fairly individualistic, with an inclination to spiritualise. The Holy Spirit is not mentioned often at all and is certainly not invoked as a miraculous answer to all problems. Personal renewal receives strong emphasis and it seems that classic "salvation verses" are well known. Although there is a considerable emphasis on "insider and outsider" and strong support for insiders, the "saved" ("gereddes"), the rejection of outsiders is not rabid. That the church is seen as a group of embattled people who yet strive to spread light in the world is probably a reflection of the group's context.

The basic rejection of political readings of the Bible probably stems partly from the individualistic, spiritualising tendency, coupled to the need to apply the passage directly to the lives of members of the group. The broader interpretation of liberation allowed some members to apply the passage not only to the unsaved ("ongereddes"), but also to the blind spots in their own lives. The tendency to spiritualise does not seem to be simply a traditional reflex. The less restricted reading was justified from the text and was regarded as more immediately relevant to the group. What can be read as a spiritualising of liberation from one angle may, from another angle, be seen as refusal to accept a reification of politics.

The group does not consistently spiritualise. In fact, perceived problems may be as mundane as giving up smoking. Concerning the Jubilee, they all agreed, economic prosperity formed part of it, because the Jubilee inaugurates a time of plenty in all respects. There may be traces of prosperity teaching here, but it is not strongly stressed. The individualising tendency seems stronger, although it is not manifest in clear pronouncements. But then, the members of the group probably all live lives that offer little scope for significant communal action. It would be hard for them to envisage their mission (of which they are perfectly aware) as anything but a mission of individuals to other individuals.

My conclusion is that various church traditions are at work here, although the undertone is of highly conservative evangelical theology with a rather puritanical ethos. Brother Bernard certainly keeps to this line and tries to move the group in this direction. Nevertheless, members do sometimes tend to interpret the basic tradition according to their perceived needs. Probably in this case social status plays more significant role here than in some other groups, precisely because the members come from different church traditions. 


\section{Response to the world of the readers}

The group was eager, perhaps overeager, to apply the Bible to their lives. Brother Bernard explicitly said that the ultimate purpose of Bible study is "changed lives". This seems to be a view shared by all. As in the case of the interpretations of the text, the tendency was to mention plausible ideas first and to turn towards less plausible ones later on.

This came out well in the first session. The main line of application was: what Jesus suffered, we shall also suffer, therefore "there will be 'offence' in your life." The basic idea received some less plausible elaborations. The worst were mere pursuits of words. Brother Bernard applied the example of Peter who was known as a follower of Jesus by his speech to Christians who will be known by their new way of speaking. For the rest, the group tended to stereotype "worldly" reaction (rejection and ridicule) and to find solace in assurances of God's faithfulness. Clearly the need of the group to maintain its position in a fairly hostile environment (mockery) invites this application, which both consoles and encourages. The application depends on taking the life of Jesus as example for what we can expect.

Regarding the Jubilee, the group found it difficult to square the "dogmatic" position about the fullness that believers have in Christ with everyday experience. For Christians every day is a feast day - but patently this is not quite true. It was a little surprising that the group did not emphasise rewards in the afterlife at this point, but preferred to speak about how we may appropriate God's blessings in this world. The Jubilee starts with the words of Jesus, yet we have to do something to activate it in our lives. A promise - fulfilment pattern can be discerned here: the Jubilee is already given to us in the promise, but we experience the fulfilment only to the extent that we claim the promise in faith every day.

\section{Concluding remarks}

That this project studied groups hardly known to the researchers and tried to draw conclusions from fairly restricted examples has always bothered me. The groups are not given the opportunity to "answer back", nor would they be able to use such an opportunity to much effect, being less articulate than those who spin together words for a living. When I viewed the videos of this group for the first time, I found much to criticise. When I viewed them again, I decided that the group would find much to criticise in me as well. On behalf of the group, I would like to "talk back" on two issues where I find an element of talking back implicit in the discussion. Obviously my attempt to articulate for others is also an imposition.

a) You suggest that we spiritualise the Bible and neglect the literal, material reading. Well, we would gladly take the material benefits, if you can show them to us. John, my neighbour, is blind. Make him see. I owe Edgars R2000. Pay it for me. But don't get Jakes out of jail or he'll start robbing us again ${ }^{10}$. We are oppressed by people talking down at us. And you (the research group) may be part of them. If Jesus simply promised a few handouts, we would not believe in Him. Others promised the same and nothing came of the promises. If Jesus promised to make everything perfect here and now, $\mathrm{He}$ was obviously a cheat or a madman.

10. I take my cue here from brother Bernard, who talked about the wrong way of celebrating the Jubilee and referred to criminals who enjoy "Jubilee" when they are free to commit crimes. 
Our reading makes sense to us and gets us through our lives. Your reading seems like daydreaming to us. Our reading is close to our lives; yours is far away ${ }^{11}$. Our reading doesn't give us everything we want, but it gives us much of what we need especially hope. If we do not take such passages from the Bible as poetic promises of a life that is full in every way, we would not be able to be thankful for small mercies and would lose the joy we already have in the large mercies we expect ${ }^{12}$. You offer too little.

b) You think we are silly because we don't want to mix the Bible and politics. That is because politics worked for you ${ }^{13}$. The Bible worked for us. The politicians promised us freedom, but they didn't free us from drugs and gangs. The politicians promised us better salaries. They forgot to add "and fewer jobs". The politicians gave us our rights so now we can buy houses in Plattekloof or walk here in the streets at night. Big joke. To the politicians we count one vote each; to God each one of us is worth more ${ }^{14}$. The Bible didn't give us many material things either, but it helped us cope without them.

You think we desperately need material things because we have so little. We think you desperately need material things because you have always had so much. You think we escape into wishful thinking; we think you are trying to escape from your guilt. We managed to get rid of some of ours. We value the friendships we get through our faith ${ }^{15}$. Is there any friendship in politics? We say we need new laws; we know that we need more than laws. We need grace. The Bible has brought some grace and some graciousness in our lives. Are you going to take the bit of beauty away from us because it is not according to your law?

Anyway, we vote in elections and do a bit here and there. Do you do more? Or do you want us to run as screaming mobs down the streets, shooting and burning? Do you really want to take the little dignity we have away from us as well? Probably that's not it. You simply want something to write about in your learned way. You think we are naïve to find the word of God in the Bible; we think you are terribly naïve to think what you write means anything at all.

11. My impression was that some political readings were rejected because they did not yield immediate applications.

12. I take my cue here from the member who implied that political preaching did not give him a sense of personal worth and purpose.

13. In the rejection of political readings I detected a sense of distrust, powerlessness and betrayal.

14. It seemed to me that the sense of "mattering" was of great importance to many members of the group. It was clear in the remark of one of the young people concerning Zechariah 2:8.

15. Throughout the two sessions, much emphasis was placed on close personal relationships. 